\title{
THE CONFLICT BETWEEN LIVED RELIGION AND STATE CONTROL OF POOR RELIEF. THE CASE OF EMMA MÄKINEN'S PRIVATE ORPHANAGE AT THE TURN OF THE 20TH CENTURY
}

\author{
JOHANNA ANNOLA* \\ University of Tampere
}

\begin{abstract}
The article discusses the conflict between lived religion and the state control of poor relief in a modernizing society by analysing the case of Emma Mäkinen's private orphanage. Emma Mäkinen's philanthropic work among neglected children was motivated by her Evangelical Revivalist conviction. Because of her trust in the transformative power of faith, she considered it appropriate to establish an orphanage next to a shelter for 'fallen' women. This decision led her onto a collision course with the State Inspector of Poor Relief and the general public, who did not share her religious views but emphasized the legislative and moral aspects vis-à-vis organizing social work. The conflict demonstrates, firstly, how the ancien régime and the traditional religious authority of the Evangelical Lutheran state church in particular was challenged by individual agency in voluntary associations such as the Evangelical Revivalist Free Mission. Secondly, the case of Emma Mäkinen's orphanage reflects how new kinds of boundaries were created by the encroaching of state control into the sphere of private philanthropy, followed by the strengthening role of scientific theories and nationalistic thinking in social work. Thirdly, the conflict opens up a view on border-crossings, thus emphasizing the undefined nature of a modernizing society.
\end{abstract}

KEY WORDS: revivalism, philanthropy, poor relief, state control, modernization

\section{Introduction}

In February 1890, a Finnish newspaper Nya Pressen reported on an outbreak of a venereal disease in a private orphanage on the outskirts of Helsinki. According to the newspaper, four girls, the youngest of whom was 12 years old, were taken to a clinic for further investigation. While one of the girls was given a clean bill of health, the three others were diagnosed with syphilis and treated accordingly $(\mathrm{NP}$ 18.2.1890).

What was especially peculiar in the case was the location of the orphanage: it was situated in an annex to a private shelter for 'fallen' women-an institution for

* JOHANNA ANNOLA (PhD 2011, University of Tampere, Finland) is research fellow at the University of Tampere. She is affiliated to the Finnish Centre of Excellence in Historical Research. Email: johanna.annola@uta.fi. 
prostitutes and other women who were regarded as morally corrupt. As there was reason to suspect that the children had been infected because of their close contact with the women in the shelter, the state authorities intervened. Both the orphanage and the shelter were inspected by Gustaf Adolf Helsingius ${ }^{1}$, State Inspector of Poor Relief, who demanded that the two asylums be separated from each other immediately (NP 11.4.1890).

A new kind of state office, the Inspector of Poor Relief, had been introduced in the Grand Duchy of Finland as the first country in Northern Europe two years prior to the syphilis outbreak. The Inspector was the highest authority in Finnish public sector poor relief, responsible for ensuring that the existing poor relief and health legislations were observed in the municipalities. In case of possible omissions, the Inspector was obliged to report to the Governor of the province in question, who initiated medical and police investigations if necessary. Thus the establishment of the office significantly intensified the state control over the municipalities (Pulma 1990: 178; Jaakkola 1994, 116-117; Pulma 1995: 106-107).

The Inspector was also responsible for ensuring that private philanthropic institutions obeyed the laws. Moreover, he was required to see that social work in private philanthropic institutions did not conflict with municipal poor relief. It was his duty to counsel the management of private institutions to change their practices if significant shortcomings were found. As in the case of public sector poor relief, the Inspector was to report to the Governor if the management of a private institution refused to take action to remedy any perceived shortcomings.

Inspector Helsingius took an interest in the orphanage by virtue of the abovementioned definition of his responsibilities. According to Helsingius, it was against the existing health regulations to let the morally corrupt inmates live in the same premises as the 'respectable' ones, or to allow sick inmates to mingle with healthy ones in an institution. Helsingius suggested that as there was reason to suspect that the syphilis had originated in the shelter for 'fallen' women and spread to the orphanage unhindered, the management had not taken heed of the health regulations (NP 11.4.1890; NP 19.4.1890).

The orphanage and the shelter for 'fallen' women were managed by an Evangelical Revivalist teacher called Emma Mäkinen. ${ }^{2}$ She had found her spiritual home with the Free Mission, an originally Anglo-American Evangelical Revivalist movement, which gained popularity in Helsinki in the late 1870s. The thought of serving Christ in the weak was central to the members of the Free Mission. Emma Mäkinen's conversion from Lutheran Christianity to Evangelical Christianity in

1 Gustaf Adolf Helsingius (1855-1934) was the son of the pastor of Lohja parish. He graduated from Helsinki Polytechnic School in 1879, but gave up his work as a railway engineer for a career in the state control of poor relief (Harjula 2004: 748-754).

2 Emma Mäkinen (née Åhman, 1849-1915) graduated from Jyväskylä Teachers' College in 1870 and worked as a teacher between the years 1870-1880. She married Free Mission evangelist Antti Mäkinen in 1886 (Markkola 2005: 818-819). 
1879 led her to abandon her career as a primary school teacher to work among 'fallen women' and neglected children. Mäkinen established a shelter for 'fallen' women in 1880 and an orphanage next to it in 1883 (Annola 2003; 157-160). In 1890, there were a total of 32 children at the orphanage, both boys and girls of all ages. At the same time, there were 22 inmates in the shelter for 'fallen' women, some of them as young as seventeen (NP 18.2.1890).

The majority of the inmates in Mäkinen's shelter for 'fallen' women were not actual prostitutes but women who had deviated from contemporary feminine purity norms. The most obvious deviation was extramarital sexual activity, which manifested itself in giving birth to an illegitimate child. A woman could also lose her reputation and be deemed to have 'fallen' by committing a crime, drinking alcohol, dressing inappropriately, behaving unconventionally, appearing in public at indecent times or in dubious company or neglecting her children (Häggman 1994; Whiteaker 1997; Lützen 1998; Markkola 2000; Annola 2003; Valverde 2008). The main objective of Emma Mäkinen's shelter was to 'raise' the 'fallen' women by teaching them orderliness and practical household skills which they could use to find respectable employment (Markkola 2002: 236-237; Annola 2003: 164; Markkola 2011: 160).

Emma Mäkinen, who considered the two institutions to be her religious vocation, reacted strongly to the way the syphilis incident was discussed in public. In order to set matters straight and to put an end to rumours, she published her own rejoinder in the press. While conceding that syphilis infection had indeed spread to her orphanage, she emphasized that it had been an isolated mishap, not a consequence of long-term mismanagement of the institution. In addition, Mäkinen published her correspondence with Inspector Helsingius and her letter to the Governor of Uusimaa Province in Nya Pressen (NP 20.2.1890; NP 11.4.1890).

However, Mäkinen's action did not pacify the situation. Instead, a public controversy arose in the press, and two factions were formed. On the one side there was Inspector Helsingius backed up by a group of concerned citizens, who were absolutely horrified by the fact that innocent children had been exposed to a venereal disease because of Mäkinen's negligent management of the orphanage. On the other side there were Emma Mäkinen and her sympathizers, many of whom were probably Evangelical Revivalists.

By analysing the debate this article discusses the case of Emma Mäkinen's private orphanage as an example of a conflict between lived religion and the state control of poor relief in Finland at the turn of the 20th century. The term lived religion refers here to an Evangelical Revivalist perception of faith, according to which Christian conviction was a choice that was to guide both the thoughts and the deeds of an individual. According to Pirjo Markkola, Evangelical Revivalism emphasized that everyone should and could be saved, which resulted in the initiation of a plethora of Evangelical philanthropic endeavours in both Europe and North America (Markkola 2002: 430-433). 
In a broader sense, the conflict between lived religion and the state control of poor relief sheds light on a modernizing society. It was characterized, firstly, by the increasing civic activity in the press, in voluntary associations and in religious movements that positioned themselves outside the sphere of the Evangelical Lutheran state church; secondly, by the expanding role of the state; and thirdly, by a new understanding of social work as a means of safeguarding the morals of society.

Emma Mäkinen and Gustaf Adolf Helsingius are the two main protagonists of this article. What makes the interplay between Mäkinen and Helsingius especially interesting is the fact that their contemporaries considered both of them to be prominent agents on their respective fields. While Mäkinen's institutions were counted among the first and most ambitious Finnish examples of Evangelical Revivalist philanthropy (Markkola 2002: 235, 245-246; Annola 2003: 162), Helsingius was the first man to hold the office of State Inspector of Poor Relief. He has been referred to as 'the founding father' of Finnish public sector poor relief (Pulma 1995: 110, 122-123; Satka 1995: 34; Annola 2011: 39-40). Therefore it is fair to assume that the conflict between lived religion and the expanding role of the state was personified in Mäkinen and Helsingius.

The philanthropic work of Emma Mäkinen has previously been analysed by Pirjo Markkola (2002; 2011) and the present author (Annola 2001; 2003). The establishment of the Inspector's office and G. A. Helsingius' proceedings have been discussed by Veikko Piirainen (1958), Panu Pulma (1995), Mirja Satka (1995), and myself (2011; 2013).

The source material of this article consists of small items of news and letters to the editor published in the spring of 1890. Most of them appeared in Nya Pressen, which was a Helsinki-based newspaper, traditionally favoured by the Swedishspeaking upper classes of the capital. This was probably because both Inspector Helsingius and many of the leading figures of the Free Mission were recruited from these circles.

The article proceeds as follows. The first section describes the controversy on the outbreak of syphilis in the orphanage in the wider contemporary context in order to understand why a relatively minor incident led to a public argument in the press. In the second and third sections the pivotal role of lived religion in the philanthropic work of Emma Mäkinen is discussed as a reason for the parties to the controversy failing to find common ground.

\section{At the Interface of Public and Private}

The debate on the outbreak of syphilis in Emma Mäkinen's orphanage is an example of a situation where a state official intervened in private philanthropy. Thus the debate is linked to the demarcation process between public sector social work and private philanthropy, and also to the discussion on the role of social work as 
the mediator of contemporary moral norms. These questions will be analysed in the following.

The rejoinders of Emma Mäkinen and her supporters indicate that the boundaries of the Inspector's legal power were unclear to the general public. In the first place, the ambiguity resulted in objection. In her rejoinders to Helsingius and later in addressing the Governor of Uusimaa Province, Emma Mäkinen went to great pains to explain that Helsingius' allegations were groundless. She noted, firstly, that the syphilis infection probably did not originate from the shelter for 'fallen' women but was brought into the orphanage by one of the children; secondly, that the sick child had been placed in a separate room as soon as it had become obvious that she was sick; and thirdly, that the children were not living in the same building as the 'fallen' women. According to Mäkinen, the sporadic encounters between the children and the women always took place under strict supervision. As for Inspector Helsingius' request to separate the orphanage from the shelter, Mäkinen stated that even though having two separate institutions would certainly be an ideal solution, she could not finance such an expensive enterprise. The orphanage was to stay as it was (NP 11.4.1890; NP 25.4.1890).

Moreover, Emma Mäkinen and her supporters questioned Helsingius' right to interfere at all with the management of the orphanage. Mäkinen suggested that it was not Helsingius' place to impose expensive corrective measures on private philanthropic institutions (NP 11.4.1890; NP 25.4.1890). She was backed up by an anonymous supporter '-ei-', ${ }^{3}$ who wrote in Nya Pressen: 'One could ask what gives the Inspector the right to demand that Mrs. Mäkinen should take the responsibility for new heavy expenses in her private charitable institution, which (...) is supported by neither the state nor the municipality?' (NP 15.4.1890).

In Helsingius' opinion, however, the practices in private philanthropy were to be brought into line with the developing standards of poor relief. In this case, the standards stemmed from a new understanding of the mental development of children which was gaining ground at the end of the 19th century. According to this view, a society could combat moral corruption by raising its children into decent citizens. Therefore special attention was to be paid to the mental and physical environment in which children were brought up. As children were regarded as fragile beings who could easily be corrupted if exposed to the company of immoral adults, every means necessary was to be taken to keep them out of the adults' sphere of influence (Pulma 1987; Hämäläinen 2007).

3 It is possible that '-ei-' was Edvard Björkenheim (1856-1934), who owned a large estate in Isokyrö, Western Finland. He was a Free Mission activist, who gave financial support to Emma Mäkinen's institutions. He was a friend of both Emma Mäkinen and her husband-and a schoolmate of G. A. Helsingius from Turku primary school (Mäkinen 2003: 630-632; Letter Collection of Edvard and Ingrid Björkenheim; Björkenheim 1915). 
Helsingius was convinced that if private philanthropy was not aligned with public sector poor relief, it could undermine the effectiveness of poor relief. Over the years, Helsingius came to perceive the relationship between private philanthropy and public sector poor relief as somewhat problematic. According to him, the mission of poor relief was not only to provide food and shelter for the needy, but also to encourage the able-bodied poor to take care of themselves. Therefore it was not rational to give the able-bodied poor alms without demanding work in return. From Helsingius' point of view, private philanthropists could endanger the mission by giving assistance too easily. Similarly, whereas poorhouse directors were expected to fight against the spread of moral corruption by keeping the depraved inmates apart from the 'respectable' ones, the negligent managers of private institutions could unbalance the situation by not classifying the inmates (Annola 2011: 223).

One of Helsingius' claims against Emma Mäkinen's orphanage centred round the very presumption that the existence of the orphanage as such, annexed to the shelter for 'fallen' women, could work contrary to municipal poor relief. This claim, too, was rejected by both Emma Mäkinen and her supporters. Mäkinen's rejoinders indicate that she was aware that according to the Poor Relief Act of 1879 , every able-bodied adult was obliged to support not only him/herself but also his/her offspring. Municipal poor relief was therefore responsible for providing only for those children who had no parents. In Emma Mäkinen's judgment, her orphanage was actually supplementing municipal poor relief by helping those children whose parents were alive but could not take proper care of their offspring, and by offering a home for women with illegitimate children (NP 11.4.1890; NP 15.4.1890; NP 25.4.1890).

Although Emma Mäkinen and her supporters emphasized the difference between private philanthropy and public sector poor relief, Mäkinen's institutions were actually semi-public institutions. On the one hand, the operational costs were mostly covered by private donations and the small-scale laundry, ironing and handicrafts businesses in which the inmates of the shelter were expected to engage themselves. On the other hand, however, Emma Mäkinen relied on public finance more than once: in 1885 she was granted a state loan of 40000 Finnish marks to build new premises for the institutions, in 1887 the Governor's Office donated 2500 Finnish marks, and from 1890 onwards the Senate subsidized the shelter with 5000 Finnish marks annually. Moreover, the orphanage received modest monthly support from the municipal poor relief funds (Annola 2001: 39-47; Markkola 2002: 239-240; Annola 2003: 160-161).

Apart from the flawed argument of the anonymous supporter '-ei-', the public funding of Emma Mäkinen's institutions did not emerge in the discussion. It seems likely that the general public was not totally aware of the structure of the funding, especially as the Senate subsidization period had only begun a couple of months earlier (SWL 25.10.1890). Rather, Mäkinen's institutions had been pro- 
filed as prime examples of private, religiously motivated philanthropy, which is why private donations were mentioned more than once. The participants used the discussion as an opportunity to campaign both for and against donating money to Mäkinen's institutions.

Those taking a stand against the orphanage claimed that it was their duty to reveal the truth about the dubious conditions in the institution because it was funded by private donations (NP 18.2.1890). In their view, people who were generous enough to donate money to the orphanage and the shelter for 'fallen' women had a right to know that they might actually be contributing to moral corruption. More maliciously, one of the critics suggested that Emma Mäkinen had published her correspondence with Inspector Helsingius in Nya Pressen only to gain the approval of the general public, whose benevolence was her financial lifeline (NP 27.4.1890).

Second, the ambiguity regarding the Inspector's legal power caused acrimony. Emma Mäkinen and her supporters were apparently annoyed by Helsingius' interference, which they considered unfair. In her letter to the Governor of Uusimaa Province, published in the press, Emma Mäkinen veiled her annoyance in lamenting: 'It seems peculiar that people [Mäkinen was actually referring to Helsingius] have taken such a great interest in ruining this small-scale work for neglected children, which is only a drop in the ocean in regard to everything that ought to be done' (NP 25.4.1890). Mäkinen stated that she would close her orphanage if it was not needed, but as long as there were children living in 'unhealthy and dirty dwellings, with nothing but vice in front of their eyes', her work was certainly necessary.

While Mäkinen managed to keep her tone neutral, some of her supporters expressed their irritation by resorting to derisive remarks about Inspector Helsingius and his actions. For example, an anonymous person under the pseudonym '-ei-' stated in an ironic tone that the authorities should be interested in finding out whether their allegations were based on real facts or on 'a mere conjecture or a rumour'. He went on to suggest that the authorities take the trouble to ascertain whether the possible shortcomings were caused by a fault in the management of the organization or if they were just a temporary mishap that could happen anywhere (NP 30.4.1890).

Emma Mäkinen's and her supporters' opposition and displeasure regarding Inspector Helsingius bears a resemblance to the situation in public sector poor relief. There, too, the demarcation line between state control and the traditional sphere of municipal self-government tended to be unclear. Numerous conflicts arose because of Helsingius' rejection of the methods of poor relief favoured by the municipal decision-makers (Pulma 1995: 110; Annola 2011: 47-48).

Similarities can be found especially between the case of Emma Mäkinen's orphanage and Helsingius' crusade to get children out of the poorhouses. According to Helsingius, municipal poorhouses were usually occupied by morally corrupt 
inmates who might exert an evil influence on the young. Therefore children were not to be put in poorhouses unless there was a separate building in the institution to house an orphanage. However, as establishing an orphanage was often considered too expensive an endeavour by municipal decision-makers, they were reluctant to agree to Helsingius' demands. More than once, the disagreements between municipal decision-makers and Inspector Helsingius in regard to keeping children in a poorhouse had to be resolved in the Governor's office (Jaakkola 1994: 135-137; Annola 2011: 180-181).

Because Emma Mäkinen refused to separate the orphanage from the shelter for 'fallen' women, the Inspector of Poor Relief reported the case to the Governor of Uusimaa Province. According to a statement published in the press, the Governor ordered the institutions to be inspected by the health authorities of the state. As the inspection found no cause for complaint from a sanitary viewpoint, it was concluded that the outbreak of syphilis in the orphanage was indeed an isolated incident. Emma Mäkinen was allowed to continue her philanthropic work as before. However, in future she was to keep the children strictly apart from the women, and also to ensure that all new inmates were given a medical examination to detect possible cases of venereal disease in time. Were Emma Mäkinen not to obey the orders, she was to be fined one hundred Finnish marks (Finland 9.5.1890, 29.7.1890; NP 28.7.1890; WL 2.8.1890).

\section{Lived Religion as Guiding Principle in Social Work}

For Emma Mäkinen, her philanthropic work among the 'fallen' women and neglected children was first and foremost a religious vocation, which generated a fundamental difference of opinion between her and her opponents in the debate of 1890. Mäkinen's religious vocation and its reception among the public are analysed below, including a discussion of the extent to which the controversy refers to the tense relationship between Evangelical Revivalist Free Mission and the Evangelical Lutheran state church.

When reporting on the outbreak of syphilis at the orphanage, the newspaper Nya Pressen stated that Emma Mäkinen was plainly 'experimenting with defenseless children' by establishing an orphanage next to a shelter for 'fallen' women. After all, the shelter could be regarded as nothing but 'a nest of individuals who had been dregs of society a couple of weeks earlier, and would probably return to being such the very next day' (NP 18.2.1890; NP 20.2.1890; NP 11.4.1890).

For Emma Mäkinen, the proximity of the shelter and the orphanage was not a problem for two reasons. First, she did not share her opponents' view of the 'fallen' women as something irreversibly corrupt. For Mäkinen, the 'fallen' women were helpless girls who had drifted into bad company because of their poverty or ignorance. They were victims of circumstances, who could be redeemed by offering them a helping hand (Annola 2003: 167). Mäkinen's way of picturing the 'fallen' women as victims was typical of European and North American philan- 
thropists, who sought to justify their controlling activities by reducing their protégées to powerless children (Mahood 1990; Vammen 1998; Markkola 2002; Jansdotter 2004).

On the other hand, Mäkinen's understanding stemmed from the fact that she herself was an illegitimate child of a maidservant. Her mother, Kristina Grönlund, was originally a rural girl who had come to Helsinki at the age of 19. Before giving birth to Emma in 1849, she had already been delivered of a son, who had died in infancy (Vihti Moving Records 1811-1841; Helsinki Birth Records 1837-1844, 1845-1851; Helsinki Records of Deaths and Burials 1827-1842). While Kristina Grönlund had been lucky enough to find employment and eventually contract a marriage, this was not the case for all young women entering the capital-in fact, most prostitutes in Helsinki were incoming rural girls with no place to go (Häkkinen 1995: 127). Emma Mäkinen wanted to save the girls from sinking into actual prostitution by offering them a decent home and decent work.

Emma Mäkinen likewise emphasized the unfortunate circumstances in regard to the children in the orphanage. According to her, most of them came from poor homes. Their parents were usually alcoholics who either abused their children or totally neglected them. Because the home life of these children was virtually nonexistent, they were 'wandering around in the streets, seeking for place to stay for a night, crawling on the ground, intoxicated'. Therefore it was certainly better for them to be brought up in the orphanage, where they would have food, shelter and clean clothes (NP 25.4.1890).

Second, Emma Mäkinen did not consider the co-existence of the shelter and the orphanage to be morally questionable because of the special atmosphere that prevailed in both institutions. In her rejoinder to Inspector Helsingius, Mäkinen described the conditions as follows: 'In a moral sense, we have never noticed that the closeness of the shelter would have damaged the orphanage during their seven years of co-existence. That is made possible by the Christian spirit and industriousness that prevail in the institutions, as well as by the fact that both the older and the younger are under constant supervision' (NP 11.4.1890).

Emma Mäkinen's remark on 'Christian spirit' is the key to understanding her work among the children and 'fallen' women. Mäkinen's notion of 'Christian spirit' was bound to her strong trust in the transformative power of Christian faith, which had changed her own life. Since Emma Mäkinen's involvement with the Free Mission and her conversion in 1879, faith had been the guiding principle of her life. At times, following this principle had led to major changes, the most ambitious of which was the establishment of the shelter for 'fallen' women only a year after her conversion.

It is likely that Mäkinen's rapid transformation from a primary school teacher into a manager of a philanthropic institution was influenced by the way conversion itself was emphasized within the Free Mission: a convert was expected to change her life by making a break with everything that was considered 'worldly' 
(Heikkilä \& Seppo 1989: 82-83; Markkola 2002: 73-83; Annola 2003: 157-159). For Emma Mäkinen, abandoning her previous career was a way of securing a place of her own among her new Evangelical community. Moreover, as nonLutherans were not allowed to teach religion at schools, Emma Mäkinen's career as a teacher would have become more difficult, if not impossible, after she was rebaptized in 1883 (Annola 2001: 37).

At the same time, however, Emma Mäkinen genuinely considered the establishment of the shelter to be her calling, a special mission from God. Mäkinen's understanding of herself as a humble instrument in the hands of God is revealed in a letter her friend Mia Sahlberg wrote to their mutual Free Mission friend Edvard Björkenheim in the autumn of 1880: 'I am sure you have (...) heard of the urgent need of a shelter here, and of how the Lord has put this very issue into Emma's heart. Emma is willing to leave everything behind in order to serve Jesus in these unhappy fallen creatures, who live in misery, loathed by themselves and the others. It is joyful to see how Emma has no other doubts but: Does the Lord want this right now? And does He want me to do it?' (Sahlberg 1880).

Thus for Emma Mäkinen, faith was not merely a tool for spiritual reinforcement. In Mäkinen's view, God actually kept watch over both the shelter and the orphanage. She assumed trustingly that no insurmountable economic problems would arise were it God's will that the institutions should flourish. It was Mäkinen's understanding that God took care of the institutions' economic situation by encouraging private persons to donate money to the cause. As for the leaner periods, Emma Mäkinen considered them to be God's way of testing her faith and patience. Mäkinen's inclination to link economic issues with God's will made it difficult for her to accept public funding for her institutions. It was only after a long inner struggle that she applied for the state loan in 1885 and for the annual Senate subsidy in 1889 (Markkola 2002: 239-240; Annola 2003: 160-161; Markkola 2011: 163-164).

In Mäkinen's case, the thought of 'raising' the 'fallen' women was linked with the transformative power of faith she had herself experienced: if faith had changed her life, surely it could also change the lives of the inmates? She did not force conversion on the inmates, however, because according to the Free Mission perception of faith, conversion was a personal decision everyone was supposed to make for him/herself. Instead, Emma Mäkinen sought to imbue the shelter and the orphanage with a 'Christian spirit' in order to create a morally upright and loving atmosphere, which encouraged the inmates to pursue orderly conduct, selfimprovement-and in some cases, even conversion.

In the controversy surrounding the outbreak of syphilis in the orphanage, Mäkinen's confidence in the power of the 'Christian spirit' in her institutions became manifest in the way she compared the orphanage to the venereal disease clinic. Although Emma Mäkinen admitted that the syphilis had probably spread in the orphanage because of her deliberate choice not to send the first patient to the 
clinic immediately, she clearly considered her institutions to be fundamentally different from the clinic: 'Earlier in the previous year, a 12-year-old girl, who had been treated for an unknown illness for a couple of months, was diagnosed with a venereal disease. I refrained from sending her to the clinic, because I knew that loose women and children are kept in the same rooms there, without being supervised or kept busy, which creates preconditions for moral depravity. Instead, I organized a room of her own with a separate entrance, and let her be taken to the doctor at given times. [She] was sent to the clinic only later on, as-to my regretwe discovered that two other children and a young woman staying in the orphanage in order to take care of her baby, had been infected as well.' (NP 25.4.1890).

Emma Mäkinen's understanding of the morally protective influence of the 'Christian spirit', meaningful work and constant supervision contributed to the fact that in her mind, the way children spent time with 'fallen' women in the clinic had nothing at all to do with the way that the very same thing happened in her institutions. According to Emma Mäkinen, the co-existence of women and children in the clinic could only lead to the moral corruption of the children. However, as Mäkinen described in Nya Pressen, the co-existence of women and children in her institutions was an arrangement which could have fortunate consequences. Without actually using the word 'family', she referred to the moments when all inmates spent time together like a large family. She explained that the women and the children had sometimes 'attended times of prayer or festivities together, and the singing and rejoicing of the children has had a good impact on the older ones' (NP 25.4.1890).

Emma Mäkinen also argued that the children's wretched background considered, their casual encounters with 'fallen' women in the shelter were not harmful. After all, the women, who were being integrated into an organized and industrious life in the shelter, could serve as the only examples of such a life for the children. Moreover, the fact that the women were invariably punished if they broke the rules of the shelter, could serve as a valuable lesson to those children who were old enough to understand what was going on (NP 20.2.1890).

\section{'Christian Spirit' and Public Response}

Inspector Helsingius did not comment on Emma Mäkinen's understanding of the role of the 'Christian spirit' in the management of the orphanage and the shelter. This was probably because engaging in religious debate was not among his official duties. His reluctance to take a stand on this particular issue may also have stemmed from the fact that as a religious individual (Harjula 2004: 748-751), he actually came to agree with Emma Mäkinen. When writing instructions for poorhouses in 1899, Inspector Helsingius emphasized the importance of the "Christian spirit' in the management of a poorhouse. According to him, it was necessary for the director of a poorhouse to be strict towards the inmates, but the strictness 
could be combined with the lenience typical of a 'true Christian' (Helsingius 1899: 93).

It should be noted, however, that in the case of Helsingius and his instructions, 'Christian spirit' and faith in general were not understood as the sole guiding principle for life at the poorhouse. Rather, religious behaviour was one of the tools for managing the institution. Helsingius stated that if the director of the poorhouse worked 'in the spirit of Christ', reverence for God would gain ground among the inmates. This, in turn, would make the inmates more peaceful and therefore easier to control. Moreover, Helsingius never encouraged poorhouse directors to go against the existing legislation or norms. Religious behaviour was to be subordinate to obeying the law and following the contemporary moral code.

The others involved, however, noted Emma Mäkinen's remark on the 'Christian spirit'. As expected, Mäkinen's supporters shared her perception of 'Christian spirit' as the central factor that contributed to the success of the orphanage and the shelter for 'fallen' women. One of them stated in the newspaper Satakunta that even though some of Mäkinen's inmates had reverted to vice after leaving the institution, the success rate of the shelter was still higher than one could expect. According to the anonymous writer, it had been thought that women who fell in immorality and drunkenness' were lost beyond redemption. In that sense, Emma Mäkinen had succeeded in curing the incurable. The reason for Mäkinen's success was the 'Christian way of life' that prevailed in the shelter. Christianity was the key to turning life in an institution into a family life, which had a beneficial effect on the inmates (Satakunta 22.3.1890).

Similarly, in his contribution, Pastor Elis Bergroth sought to draw public attention to the family-like conditions prevailing in Emma Mäkinen's orphanage. He described the orphanage and its inmates in warm words: 'Their healthy little faces were so merry and trusting. They had grown up under the sunshine of love. Their small beds looked so inviting, the simple household goods, and the paintings on the walls, everything contributed to the indescribable spirit of home, without which the upbringing of children cannot be successful.' In Pastor Bergroth's opinion, one could hardly give his/her mite for a better cause than supporting Mäkinen's institutions, which is why he urged the public to be generous in their support in the upcoming event at the Alliance House (Finland 5.5.1890).

As Bergroth was known as a strictly Lutheran pastor, who considered AngloAmerican Evangelical Revivalism and Alliance Christianity in general as a threat to the unity of the state church (Lauha 2003: 573-574), his letter can be regarded as a special concession to Mäkinen's institutions. The way Bergroth interfered in the matter thus supports Pirjo Markkola's interpretation according to which Emma Mäkinen managed to stay on good terms with Lutheranism in spite of her prominent position within the Free Mission (Markkola 2002: 245). Her good relations to Lutheranism did not contradict her Evangelical Revivalist conviction, because the Free Mission particularly emphasized Alliance Christianity, i. e. co-operation be- 
tween Christians of different denominations. Besides, for Mäkinen, cooperation with the Lutheran clergy may have been necessary for the very reason that her institutions were partially subsidized by the state.

Pastor Bergroth's letter nevertheless indicates that on a larger scale, the discussion on the outbreak of syphilis in the orphanage may have had to do with the schism between the state church and the Evangelical Revivalist Free Mission. According to Bergroth, the Evangelical Revivalists regarded the debate as a religiously motivated witch-hunt orchestrated by the state church (Finland 5.5.1890). Given that Mäkinen's philanthropic work was closely connected to the Free Mission, the notion of a witch-hunt was not far-fetched. Moreover, Emma was married to Antti Mäkinen, who was one of the leading figures of the Free Mission. The institutions served both as the meeting place for various Free Mission gatherings and as the Mäkinens' private home. Therefore attacking them would have been a good way of criticizing the Free Mission itself.

The opponents of Emma Mäkinen were not convinced by her portrayal of the central role of the 'Christian spirit' in her institutions. In a letter published in $\mathrm{Nya}$ Pressen, it was stated that while 'Christian spirit' certainly was a powerful element, there was no evidence whatsoever of the presence of such a spirit in Mäkinen's institutions: the results of the shelter for 'fallen' women were not sufficiently convincing. Too many women had come there only to stay for a short while before returning to a life of vice. The writer(s) pointed out that 'Christian spirit is not something you put on or take off with the institutions' uniform, nor can it be guaranteed by regular prayers or remorseful lamentations' (NP 27.4.1890).

Moreover, the critics protested strongly about the picture Emma Mäkinen had painted of the family-like encounters between the children and the 'fallen' women. They claimed that Mäkinen did not have a clear overall view of the situation in the institutions: 'We do not doubt that children have a beneficial effect on the less corrupt women; their singing and innocent joy can melt even the hardest of hearts for a while, but we do ask: are these children there for the women? Are not their more sensitive minds profoundly and devastatingly influenced by the 'fallen'; a glance, a couple of ill-considered words, sanctimonious expressions are enough to dim a child's soul' (NP 27.4.1890).

In a sense, Emma Mäkinen and her supporters nevertheless prevailed in the controversy of 1890. As mentioned earlier, the two institutions were not separated. Moreover, as the Governor of Uusimaa Province characterized Mäkinen's philanthropic work as a 'successful and self-sacrificing endeavour' (NP 28.7.1890), and as his statement was published in several newspapers, Mäkinen could consider her institutions to have been vindicated on the part of the state authorities. It may, however, be that in the long run, Mäkinen's decision to publish her correspondence with the state authorities was a mistake. The shortcomings of Mäkinen's institutions, which had been brought to the fore in the controversy in 1890 , were not forgotten by the general public. A seed of doubt and mistrust had been 
sown in people's minds. The co-existence of the orphanage and the shelter had become an awkward issue, which was dredged up every time Mäkinen faced difficulties in managing her institutions.

In 1900, Emma Mäkinen's husband Antti Mäkinen had an affair with one of the inmates in the shelter for 'fallen' women. As a consequence, the inner circle of the Free Mission woke up to the thought that the shelter could be considered a den of vice-and that the company of its inmates could indeed have a harmful impact on the children in the orphanage. Emma Mäkinen described the oppressive atmosphere in a letter to her husband: 'As the matter now spreads like wildfire, I do understand that our friends [in the Free Mission] will be put at a disadvantage because of us. I do not write this in order to hurt you time after time but because I want you to know how things are. I was nevertheless delighted that Mimmi ${ }^{4}$ expressed her sympathies and that she considered it impossible that something like that could have happened here. I mean, that she evaluated the atmosphere the way she did-and not like many of the believers, who think that the air here is so foul that no-one can remain pure. (...) The friends are now in a hurry to separate the orphanage from the shelter. May the Lord help and strengthen me, as it will be difficult to find a place for the homes' (Mäkinen 1900).

Ten years earlier, Emma Mäkinen's friends in the Free Mission had stood by her when she had refused to separate the institutions from each other. Now the situation was different. The inner circle of the Free Mission realigned itself with Inspector Helsingius' standpoint, demanding that Emma Mäkinen was to reorganize her institutions either by transferring the orphanage to a rural area or by closing it altogether. It was even suggested that the donors within the Free Mission would regard it as a matter of conscience not to fund the institutions in their current state. According to Pirjo Markkola, the inner circle of the Free Mission considered Antti Mäkinen's affair to be an 'industrial accident', which undermined the credibility of Emma Mäkinen's philanthropic work and endangered the reputation of the entire Free Mission (Markkola 2002: 248-250; Annola 2003: 173174).

The turbulence within the Free Mission coincided with the growing awareness of the importance of child welfare at the beginning of the new century. The state authorities intensified their efforts to formulate guidelines for child welfare. A state committee was set in 1902, with a special emphasis on the upbringing of poor children. Although the memorandum of the committee did not lead to legislative reforms, it nevertheless standardized the methods of public sector child care by recommending the establishment of municipal boards of child welfare. One of the members of the committee was Inspector Helsingius, who in 1907 published

4 Emma Mäkinen was probably referring to her co-worker Mimmi Puupponen, who taught ironing to the women in the shelter (Annola, 2001: 54). 
an influential handbook on child welfare (Pulma 1987: 108; Harjula 2004: 750; Harrikari 2004: 129; Hämäläinen 2007: 101-104).

However, Emma Mäkinen did not give up: the plans for separating the orphanage from the shelter were not realized. Unfortunately for her, Antti Mäkinen did not give up either: in 1912, he was caught having another affair. This resulted in a major scandal both inside and outside the Free Mission, and the arguments against the co-existence of the orphanage and the shelter were reiterated in an even sharper tone than before. Antti Mäkinen was dismissed from his position as an evangelist. It is hardly a coincidence that in 1913, a new precondition appeared in the terms of the annual Senate subsidy for Emma Mäkinen's shelter for 'fallen' women: the state would not continue subsidizing the shelter if Mäkinen continued to refuse to close the orphanage. Because Emma Mäkinen could not afford to lose the subsidy for her shelter, she had no option but to close the orphanage the same year (Markkola 2002: 250-252; Annola 2003: 174). Emma Mäkinen died two years later at the age of 66.

\section{Conclusion}

The philanthropic work of Emma Mäkinen stemmed from her Evangelical Revivalist vocation, according to which everyone should serve Christ in their less fortunate neighbours. Mäkinen's way of organizing her orphanage and her shelter for 'fallen' women as well as her trust in the protective influence of a 'Christian spirit' led her into conflict with both Inspector Helsingius and the general public who did not share her religious views.

In a broader sense, the very eruption of such a conflict reflects the modernization of society. Firstly, the conflict emerged because of the increase in civic activity in the Grand Duchy of Finland at the end of the $19^{\text {th }}$ century. Emma Mäkinen's commitment to the Free Mission and the way she participated in a public controversy in the press reflect a process by which the traditional society of estates was slowly replaced by a modern civic society. Whereas the society of estates was based on privilege and the concept of subservience, modern civic society was based on the notion of liberty and the sovereignty of an individual. The new idea of sovereignty was manifest in the way people expressed themselves through the expanding press and their activity in a growing number of voluntary associations such as the Free Mission: the ideology was one of encountering each other as fellow citizens, free from the boundaries imposed by the old system of four estates (Alapuro et al. 1989).

The controversy over Emma Mäkinen's orphanage indicates that the emergence of voluntary associations was not always unproblematic if these associations appeared to challenge the traditional authority of the state. For example, many representatives of the Evangelical Lutheran state church considered Evangelical Revivalism to constitute a threat because the Evangelical Revivalist associations questioned the religious supremacy of the state church. By being re-baptized in 
1883, Emma Mäkinen challenged the state church's monopoly on baptism, and by becoming a Free Church evangelist, Antti Mäkinen questioned the state church's monopoly on preaching the gospel. From a strict Evangelical Lutheran point of view, the Mäkinens' decisions as well as their interest in Alliance Christianity vitiated the strength and unity of the state church.

Secondly, the conflict between lived religion and the state control of poor relief developed because of another phenomenon typical of a modernizing society: bureaucratization. While old boundaries were challenged by the emergence of voluntary associations, new ones were created by the simultaneous expansion of state control. The responsibility for local-level poor relief was transferred from the parishes to the municipalities in 1865, and municipal poor relief was subjected to state control by the establishment in 1888 of the office of State Inspector of Poor Relief. The change manifested in a constant struggle between the old forms of poor relief often favoured by the municipal decision-makers, and the new practices of institutionalized poor relief propagated by the state officials.

Similarly, the regulations related to the Inspector's office reserved for the state the right to intervene in the practices used in private philanthropy. As Mäkinen's case indicates, state intervention in private philanthropy was not a straightforward process. In the 1890 s, the boundaries of the legal power of the state vis-à-vis private philanthropic institutions were still unclear to the general public, which is why the Inspector's attempts to influence the way Emma Mäkinen was managing her institutions gave rise to objections and acrimony. It is possible that in Mäkinen's case the objections reflected the strained relationship between the Free Mission and the Evangelical Lutheran state church. After all, the State Inspector's intervention in Mäkinen's philanthropic work could be considered to have been an attack against the sovereignty of the Free Mission itself.

The expansion of state control into the sphere of private philanthropy was interlinked with the diminishing influence of religion in social work. While Emma Mäkinen was managing an orphanage which was based on the Evangelical Revivalist perception of faith, the focus of public sector child care was slowly shifting from religion to bringing up children as decent citizens. The new tendency stemmed from both nationalism and scientific theories, according to which environmental factors contributed to children's physical and moral development. Thus Emma Mäkinen's understanding of the central role of the 'Christian spirit' in child care and social work in general was becoming obsolete.

The fact that the inner circle of the Free Mission abandoned Emma Mäkinen and her cause in the early 1900s reflects the pervasiveness of the new norms of child care and social work. The inner circle's decision not to support the coexistence of the orphanage and the shelter for 'fallen' women is also connected to the question of the public image of the Free Mission. In the early 1900s, the Free Mission was experiencing inner turbulence because of the morally reprehensible conduct of one of its leading figures, Antti Mäkinen. The way the inner circle of 
the Free Mission re-aligned itself with the modernizing norms of social work can be considered a strategic choice in a situation where the moral credibility of the Mission was challenged. One might also wonder whether the rejection of Emma Mäkinen as well as the dismissal of her husband were a part of the process where a new generation superseded the older members in the inner circle of the Free Mission.

In addition to the modernization process, the conflict between Emma Mäkinen's orphanage and the state control of poor relief sheds light on the undefined nature of a modernizing society. The flexibility becomes visible first in the way Emma Mäkinen and one of her supporters, the strict Lutheran pastor Elis Bergroth, were able to cross the border between Evangelical Lutheranism and Evangelical Revivalism. Their communication challenges the traditional approach to church history, which tends to take the borders of different denominations as selfevident and unbridgeable. The relationship between Emma Mäkinen and Elis Bergroth was not determined by their religious differences but a shared understanding of a Christian home as a precondition for turning neglected children into moral adults. Although they may not have found common ground on doctrinal issues, they found it vis-à-vis the social question.

Secondly, the flexibility is manifest in the way Emma Mäkinen's philanthropic work was located on the border between public sector and private sector social work. According to Mäkinen's own understanding, she was supplementing public sector poor relief by offering care for those children whose parents were alive and able-bodied but who nevertheless could not take care of their offspring. Moreover, in addition to voluntary donations, her institutions received public funding in the form of several subsidies. It should be noted that even though public sector was expanding, semi-public institutions and associations remained as an important form of social work in Finland until the 1930s.

\section{Bibliography}

Alapuro R et al (1989) Kansa liikkeessä. Helsinki: Kirjayhtymä.

Annola J (2001) 'Minulle eläminen on Kristus': uskonto ja yhteiskunnallinen äitiys Emma Mäkisen hyväntekeväisyystyössä 1849-1915. MA Thesis, University of Tampere.

Annola J (2003) 'Minulle eläminen on Kristus': uskonto ja yhteiskunnallinen äitiys Emma Mäkisen hyväntekeväisyystyössä 1849-1915. Suomen kirkkohistoriallisen seuran vuosikirja 92: 153-178.

Annola J (2011) Äiti, emäntä, virkanainen, vartija. Köyhäintalojen johtajattaret ja yhteiskunnallinen äitiys 1880-1918. Helsinki: Suomalaisen Kirjallisuuden Seura.

Annola J (2013) Valtiovalta köyhäintalon johtajan ammatin rakentajana 18801921.Janus 21(3): 192-205. 
Björkenheim E (1915) A letter from Edvard Björkenheim to G. A. Helsingius, dated 2.1.1915. G. A. Helsingius' Letter Archive I, Åbo Akademi University Library Archives, Turku, Finland.

Finland 5.5.1890, 9.5.1890, 29.7.1890.

Harjula M (2004) Gustaf Adolf Helsingius. In Klinge M et al (eds) Suomen kansallisbiografia 3. Helsinki: Suomalaisen Kirjallisuuden Seura, pp. 748-754.

Harrikari T (2004) Alaikäisyys ja rikollisuuden muuttuvat tulkinnat suomalaisessa lainsäätämiskäytännössä. Helsinki: Hakapaino.

Heikkilä M \& Seppo J (1989) Uskonnollinen liike, esivalta ja 'maailma'. In Alapuro R et al (eds) Kansa liikkeessä. Helsinki: Kirjayhtymä, pp. 70-85.

Helsingius G (1899) Handbok i fattigvård. Helsinki: J. Simelii arfvingars boktryckeri aktiebolag.

Helsinki Birth Records 1837-1844, The Archive of the Swedish-Finnish Parish in Helsinki I C:9, The National Archives of Finland, Helsinki, Finland.

Helsinki Birth Records 1845-1851, The Archive of the Swedish-Finnish Parish in Helsinki I C:10, The National Archives of Finland, Helsinki, Finland.

Helsinki Records of Deaths and Burials 1827-1842, The Archive of the SwedishFinnish Parish in Helsinki I F:2, The National Archives of Finland, Helsinki, Finland.

Häggman K (1994) Perheen vuosisata: perheen ihanne ja sivistyneistön elämäntapa 1800-luvun Suomessa. Helsinki: Suomen Historiallinen Seura.

Häkkinen A (1995) Rahasta—vaan ei rakkaudesta: prostituutio Helsingissä 1867-1939. Helsinki: Otava.

Hämäläinen J (2007) Lastensuojelun kehityslinjoja: tutkimus Suomen lastensuojelun aatepohjasta ja oppihistoriasta. Kuopio: Snellman-instituutti.

Jaakkola J (1994) Sosiaalisen kysymyksen yhteiskunta. In Jaakkola J et al (eds) Armeliaisuus, yhteisöapu, sosiaaliturva: suomalaisen sosiaalisen turvan historia. Jyväskylä: Sosiaaliturvan Keskusliitto 1994, pp. 71-161.

Jansdotter A (2004) Ansikte mot ansikte: räddningsarbete bland prostituerade kvinnor $i$ Sverige 1850-1920. Eslöv: Brutus Östlings Bokförlag Symposion.

Lauha A (2003) Elis Bergroth. In Klinge, M et al (eds) Suomen kansallisbiografia 1. Helsinki: Suomalaisen Kirjallisuuden Seura, pp. 573-574.

Letter Collection of Edvard and Ingrid Björkenheim, The Private Archive of Orisberg Manor, Isokyrö, Finland.

Lützen K (1998) Byen tammes: kernefamilie, sociale reformer og velgørenhed $i$ 1800tallets København. Copenhagen: Hans Reitzels Forlag.

Mahood L (1990) The Magdalenes: Prostitution in the Nineteenth Century. London: Routledge.

Markkola P (2000) The Calling of Women. Gender, Religion and Social Reform in Finland, 1880-1920s. In Markkola P (ed) Gender and Vocation. Women, Religion and Social Change in the Nordic Countries, 1830-1940. Helsinki: Suomalaisen Kirjallisuuden Seura, pp. 169-206. 
Markkola P (2002) Synti ja siveys: naiset, uskonto ja sosiaalinen työ Suomessa 19601920. Helsinki: Suomalaisen Kirjallisuuden Seura.

Markkola P (2005) Emma Mäkinen. In Klinge $\mathrm{M}$ et al (eds) Suomen kansallisbiografia 6. Helsinki: Suomalaisen Kirjallisuuden Seura, pp. 818-819.

Markkola P (2011) Women's Spirituality, Lived Religion and Social Reform in Finland, 1860-1920. Perichoresis 9(2): 143-181.

Mäkinen E (1900) A letter from Emma Mäkinen to Antti Mäkinen, dated 7.10.1900. Emma Mäkinen's letters to Antti Mäkinen, The Archive of the Free Mission I FB:5, The Provincial Archives of Hämeenlinna, Hämeenlinna, Finland.

Mäkinen R (2003) Edvard Björkenheim. In Klinge $\mathrm{M}$ et al (eds) Suomen kansallisbiografia 1. Helsinki: Suomalaisen Kirjallisuuden Seura, pp. 630-632.

Nya Pressen (NP) 18.2.1890, 20.2.1890, 11.4.1890, 15.4.1890, 19.4.1890, 25.4.1890, 27.4.1890, 30.4.1890, 28.7.1890.

Piirainen V (1958) Kylänkierrolta kunnalliskotiin. Savon ja Pohjois-Karjalan maaseudun vaivaishoitotoiminta vaivaishoidon murroskautena 1800-luvun jälkipuoliskolla. Helsinki: Suomen Historiallinen4 Seura.

Pulma P (1987) Kerjuuluvasta perhekuntoutukseen. In Pulma P et al (eds) Suomen lastensuojelun historia. Helsinki: Lastensuojelun Keskusliito, pp. 7-257.

Pulma P (1990) Köyhästäkö kansalainen? Köyhyys 1800-luvun poliittisena ongelmana. In Haapala P (ed) Talous, valta ja valtio: tutkimuksia 1800-luvun Suomesta. Tampere: Vastapaino, pp. 187-208.

Pulma P (1995) Valtio, vaivaiset ja kuntien itsehallinto. Gustaf Adolf Helsingius valtion ja kuntien välisen suhteen muokkaajana. In Tiihonen S (ed) Virkanyrkit ja muita hallintohistorian tutkielmia. Helsinki: Painatuskeskus, pp. 99-125.

Sahlberg M (1880) A letter from Mia Sahlberg to Edvard Björkenheim, dated 22.9.1880. Letter Collection of Edvard and Ingrid Björkenheim, The Private Archive of Orisberg Estate, Isokyrö, Finland.

Satakunta 22.3.1890.

Satka M (1995) Making Social Citizenship. Conceptual Practices from the Finnish Poor Law to professional social work. Jyväskylä: SoPhi.

Suomalainen Wirallinen Lehti 25.10.1890

Valverde M (2008) The Age of Light, Soap and Water: Moral Reform in English Canada, 1885-1925. Toronto: University of Toronto Press.

Vammen T (1998) Ambiguous Performances: Women in Copenhagen Philanthropy. In Jordansson B et al (eds) Charitable Women: Philanthropic Welfare 1780-1930. A Nordic and Interdisciplinary Anthology. Odense: Odense University Press, pp. 181-196.

Vihti Moving Records 1811-1841. Vihti Parish Archive I Bab:2. The Provincial Archives of Hämeenlinna, Hämeenlinna, Finland.

Waasan Lehti 2.8.1890. 
Whiteaker L (1997) Seduction, Prostitution, and Moral Reform in New York, 18301960. New York, NY: Garland. 